\title{
Attitude and awareness of medicinal plants in treatment of kidney lithiasis in eastern Morocco: a retrospective study
}

\author{
BOUCHRA EL GUERROUJ ${ }^{1 \oplus}$, NOUREDDINE BENCHEIKH ${ }^{2 \oplus}$, MOHAMED BOUHRIM $^{2} \odot$, \\ LOUBNA KHARCHOUFA $^{2 \oplus}{ }^{\circledR}$, HAYAT OUASSOU ${ }^{2 \odot}$, HAMADA IMTARA $^{3 \oplus}$
}

\author{
${ }^{1}$ Laboratory of Water Environment and Sustainable Development \\ Faculty of Sciences \\ Mohammed First University \\ Oujda, Morocco
}

${ }^{2}$ Laboratory of Bioresources, Biotechnology, Ethnopharmacology and Health

URAC-40, Department of Biology

Faculty of Sciences

Mohammed First University

Oujda, Morocco

${ }^{3}$ Faculty of Arts and Sciences

Arab American University Palestine

P.O. box 240

Jenin, Palestine

*corresponding author: phone: +972 592030 458; e-mail: hamada.tarayrah@gmail.com

\section{Summary}

Introduction: Kidney stone is a major public health problem. Over $5 \%$ of the population is affected by kidney stones, with causes a lifetime risk of transmitting renal lithiasis of about 8 to $10 \%$.

Objective: The goal of our study is the attitude and awareness of lithiasis patients regarding the use of medicinal plants in eastern Morocco.

Methods: We carried out a study on lithiasis patients to retrospectively identify medicinal plants used in this disease, using a pre-established questionnaire. The study was carried out from 10 December 2017 to 28 February 2018.

Results: Our survey describes several medicinal plants used to treat renal lithiasis in eastern Morocco. Most patients used Herniaria hirsuta L., Zea mays L., Urtica dioica L., and Petroselinum crispum (Mill.) Fuss. This preliminary study showed that the first reason to use medicinal plants in half of lithiasis patients is to calm the pain and expel the stones. The primary source of plant use information is oral tradition. However 67\% of lithiasis patients are unaware of the harmful and toxic effects that can appear. 
Conclusion: Medicinal plants must, like medicines, comply with strict requirements and standard rules of use to which only the specialist in herbal medicine can respond and sensitize people to the dangers of irrational consumption of medicinal plants.

Key words: renal lithiasis, medicinal plants, eastern Morocco, retrospective study

Słowa kluczowe: kamica nerkowa, rośliny lecznicze, wschodnie Maroko, badanie retrospektywne

\section{INTRODUCTION}

Urinary lithiasis or stone disease is a pathology that presents a major public health problem. It affects $10 \%$ of the population in industrialized countries [1]. It is characterized by the formation of crystalline concretions developing in a basin and/or calyxes of kidney and causing partial or total obstruction to the normal urine flow [2]. Several factors can be linked to the formation of these calculi such as sex, ethnic group, food intake, genetics, climatic aspects, and metabolic disturbances [3]. In $50 \%$ of cases, it is a recurrent disease. Some forms are particularly severe and can lead to kidney failure. Urinary lithiasis is the third cause of chronic kidney disease at 9.8\% [4]. The annual prevalence of urinary lithiasis in Western countries has nearly tripled in the last 50 years. These phenomena are explained by the rise in the socio-economic level and the change in eating habits, such as the consumption of salt, which was multiplied by 3 , and that of protein multiplied by 5 [5]. Besides, the chemical nature of the calculus has changed. The end of the $19^{\text {th }}$ century was characterized by the dominance of calculations based on purine, whereas in recent years have experienced an increase in the frequency of Oxalocalcium in three-quarters of cases. Since Morocco's eating habits change from one generation to another, the epidemiological profile of the calculations of Moroccan patients is similar to that of the industrialized countries [6]. With the increase in the number of patients and the painful nature of the disease, some patients choose the use of traditional medicines, which is mainly based on the use of plants, to meet their health care needs, which is a very old practice implemented by almost $80 \%$ of the population worldwide [7]. For centuries, our ancestors appreciated the virtues of plants. They have transmitted and developed their knowledge and experiences in the use of medicinal plants to overcome suffering and heal the wounds [8]. Today, plants still play a very important role in medical traditions worldwide. However, the rules of their use sometimes lack rigor and do not take into account the new requirements of modern therapeutics [9]. The traditional use of medicinal plants is mainly based on the idea that plants are a means of treatment without harmful effects because they are natural. Consumers believe that natural is the synonym of harmless [10]. In Eastern Morocco, studies on renal lithiasis are few and focused on the determination of the epidemiology and chemical composition of the complex preparations $[11,12]$. However, no studies have been carried out regarding the place of medicinal plants in the treatment of renal lithiasis. To contribute to the study of the place of medicinal plants in the treatment of renal lithiasis in eastern Morocco, we focused on the attitude and awareness of patients regarding the use of plants to expel kidney stones.

\section{MATERIAL AND METHODS}

\section{Study sample}

The target population consisted of 184 patients suffering from urinary stone disease in different cities of eastern Morocco. Participants interviewed were informed about the objectives of the study. All patients were informed that their personal data would be analyzed as a part of this survey and consented for their data to be included in the analysis.

\section{Epidemiological survey}

In order to highlight the attitude and awareness of lithiasis patients towards the use of medicinal plants in eastern Morocco, a study was conducted on patients with renal lithiasis to retrospectively identify the medicinal plants used, using pre-established questionnaire (fig. 1). This study was carried out through several continuous visits over a period from 10 December 2017 to 28 February 2018. The places and health services visited in this study are the hospital urology and nephrology services in nine provinces of eastern Morocco (Oujda, Berkane, Nador, Jerada, Taourirt, Saidia, Figuig, Bouarfa and Bouanane), and the urology and nephrology department of the CHU Mohammed VI of Oujda was also visited regularly (this hospital welcomes patients from different regions of Eastern Morocco with serious health problems that cannot be treated in the hospitals of their cities). Also private centres were visited (Oriental Nephrology 


\begin{tabular}{|c|c|}
\hline \multicolumn{2}{|c|}{$\begin{array}{l}\text { Retrospective study of medicinal plants used to treat kidney lithiasis. } \\
\text { Ladies and gentiemen, pleose onswer the questions corefully in order to obtoin relioble stotistics. }\end{array}$} \\
\hline \multicolumn{2}{|l|}{ J) Identification } \\
\hline $\begin{array}{l}\text { 1. What is your sex? } \\
\text { O1. Male }\end{array}$ & $\begin{array}{l}\text { 4. What is your socio-economic status? } \\
\mathrm{O}_{1} \text {. Low } \mathrm{O}_{2} \text {.Medium } \mathrm{O}_{2} \text {. High }\end{array}$ \\
\hline $\begin{array}{l}\text { 2. What is the age of reach? } \\
O_{1} \text {. Under } 30 \text { years } \quad O_{2.30} \text { to } 60 \text { years } \\
O_{3 .} \text { Over } 60 \text { years }\end{array}$ & $\begin{array}{l}\text { 5. What is your level of education? } \\
O_{1} \text {. lliterate } \mathrm{O}_{2} \text { Elementary } \mathrm{O}_{3} \text {. Secondary } \\
\mathrm{O}_{4} \text {. Superior }\end{array}$ \\
\hline \multicolumn{2}{|l|}{$\begin{array}{l}\text { 3. What is your living place? } \\
O_{1} \text {. Urbain }\end{array}$} \\
\hline \multicolumn{2}{|l|}{ II) History } \\
\hline $\begin{array}{l}\text { 6. Have you seen a doctor? } \\
O_{1} \text {. Yes } \mathrm{O}_{2} \text {. No }\end{array}$ & $\begin{array}{l}\text { 8. Is this treatment effective? } \\
\text { O1. Yes } \mathrm{O}_{2} \text {. No }\end{array}$ \\
\hline \multicolumn{2}{|l|}{$\begin{array}{l}\text { 7. If "Yes" Did you follow your treatment? } \\
\text { O1. Yes O 2. No } \\
\text { The question is only relevant if Medkal consuitotion = "Yes" }\end{array}$} \\
\hline \multicolumn{2}{|l|}{ III) Herbal medicine } \\
\hline $\begin{array}{l}\text { 9. Have you used medicinal plants to treat your disease? } \\
O_{1} \text {. Yes } \mathrm{O}_{2} \text {. No }\end{array}$ & $\begin{array}{l}\text { 14. How do you determine the dose used? } \\
\square_{1} \text {. Per pinch } \square_{6} \text {. Per spoon } \\
\square_{3} \text {. Per handle } \square_{4} \text {. Unspecified }\end{array}$ \\
\hline \multirow[t]{2}{*}{$\begin{array}{l}\text { 10. If "Yes" Did you use medicinal plants with the drug } \\
\text { treatment. } \\
O_{1} \text {. before } \mathrm{O}_{2} \text { After } \mathrm{O}_{3} \text {. In parallel } \\
\text { The question is aniy relovant if Medicinal plonts a "Yes" }\end{array}$} & $\begin{array}{l}\text { 15. How often a day do you use this plant? } \\
\square_{1} \text {. Once a day } \square_{2} \text {. Twice a day } \\
\square_{3} \text {. Three times a day } \square_{4} \text {. Several times a day }\end{array}$ \\
\hline & \multirow{2}{*}{$\begin{array}{l}\text { 16. What is the duration of treatment? } \\
\square_{1} \text {. Three days } \square_{3} \text {. One week } \\
\square_{3} \text {. Two weeks } \square_{4} \text {. One month } \\
\square \text { s. Until healing }\end{array}$} \\
\hline $\begin{array}{l}\text { 11. What plant do you use to treat kidney stones? } \\
\text { 口 1. Petroselinum crispum (لمعدوس) }\end{array}$ & \\
\hline 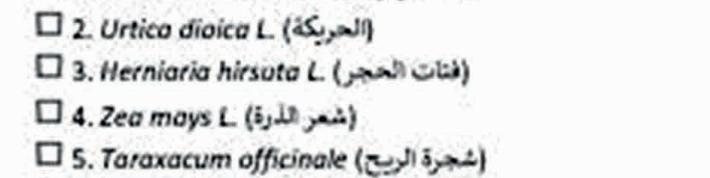 & $\begin{array}{l}\text { 17. Who advised you to use this plant? } \\
\square_{1} \text {. Herbalist } \square_{3} \text {. Former patient } \\
\square_{3} \text {. Word of mouth } \square_{6} \text { Media }\end{array}$ \\
\hline 口6. Other & \multirow{3}{*}{$\begin{array}{l}\text { 18. Why did you use this plant? } \\
\square_{1} \text {. To potentiate the effect of the drug } \\
\square_{2} \text {. Low price } \\
\square_{3} \text {. Cultural influence } \\
\square_{4} \text {. Expel Ithiasis }\end{array}$} \\
\hline rou can check seweral baves. & \\
\hline 12. If "Other" Which? & \\
\hline The question is only relevant if plobst type = 'Other' & \multirow{3}{*}{$\begin{array}{l}\text { 19. Oid you know that these plants have a toxic effect? } \\
O_{1} \text {. Yes } O_{2} \text {. No } \\
\text { 20. If "Yes" Which? }\end{array}$} \\
\hline 13. How do you prepare this plant? & \\
\hline$\square_{1 \text {. Infusion }} \square_{3}$. Decoction $\square_{3}$. Powder & \\
\hline
\end{tabular}

Figure 1.

Pre-established questionnaire 
and Hemodialysis Center and $\mathrm{Al} \mathrm{Hakim} \mathrm{Alaoui} \mathrm{He-}$ modialysis Centre in Oujda). All patients included in this study were interviewed using a pre-established questionnaire and structured into three main axes as follows: 1) gathered different identifying characteristics of the patients (sex, age, living environment, level of education), 2) specifies a patient history, which is a medical monitoring and its effectiveness, 3 ) all the modalities concerning the use of anti-lithiasis plants (identification of plants used in the treatment of lithiasis, the method of preparation, timing and frequency of intake, different sources of information about these plants, reasons for use, the patient awareness of the adverse effects of these plants.

\section{Identification of medicinal plant species}

All local plant names collected during this study were transformed into botanical names, based on the work of Jamila and Mostafa [11]. To ascertain the scientific names of plants compiled from the survey, we used a standardized database [12].

\section{Ethical}

Patients' data is kept safe and secure, to protect their confidential information. Each patient detailed information is replaced by a code, and a record was established to identify different patients. This register was only accessible to the principal investigator. Data collection and data entry was done anonymously using this code.

\section{Statistical analysis}

All data collected from respondents were copied and analysed by Microsoft Excel 2016.

Ethical approval: The conducted research is not related to either human or animal use.

\section{RESULTS AND DISCUSSION}

\section{Socio-demographic data}

The socio-demographic characteristics of lithiasis patients (places of residence, age, sex, level of education) were summarized in table 1.

\section{Distribution of lithiasis patients according to place of residence}

In this study, a total of 184 lithiasis patients were interviewed in urology departments (Al Farabi Regional Hospital and Mohamed IV University Hospital). We found that 138 lithiasis patients are from urban areas $(75 \%)$, and 46 are from rural areas with $(25 \%)$ (tab. 1). This difference can be explained by regional variations in population density [13], and the difference in lifestyle between rural and urban population.

\section{Distribution of lithiasis patients according to age}

As shown in table 1, the prevalence of urinary stones varies according to age [15]. People in the age group

Table 1.

Socio-demographic characteristics of lithiasis patients

\begin{tabular}{|c|c|c|c|}
\hline Distribution of patients & Categories & Number of patients & Percentage of patients [\%] \\
\hline \multirow{2}{*}{ By sex } & Men & 79 & 43 \\
\hline & Women & 105 & 57 \\
\hline \multirow{2}{*}{ By habitat } & Urban & 138 & 75 \\
\hline & Rural & 46 & 25 \\
\hline \multirow{3}{*}{ By age range } & $<30$ years & 48 & 26.41 \\
\hline & $30-60$ & 104 & 56.6 \\
\hline & $>60$ years & 32 & 16.98 \\
\hline \multirow{4}{*}{ By education level } & Illiterate & 42 & 23 \\
\hline & Primary education & 20 & 11 \\
\hline & Secondary education & 48 & 26 \\
\hline & University education & 74 & 40 \\
\hline
\end{tabular}


from 30 to 60 arrive first with a percentage of $53 \%$, followed by people younger than 30 (26.41\%), and over 60 are the least affected by lithiasis (16.98\%). The highest incidence of lithiasis in the age group 30 to 60 in our study is proven by other works conducted on the territory of Morocco[13, 16-18]. Also, the increase in the incidence of lithiasis in the age group 30-60 is confirmed in other studies published outside Morocco such as in Turkey, Spain, and United States [19-21].

\section{Distribution of lithiasis patients according to sex}

In this epidemiological study, out of a total of 184 lithiasis patients, 79 are men (43\%) and 105 are women (57\%) (tab. 1). The sex ratio was 1.33 . Several factors can influence the difference in the incidence among women and men, but the main factor that can be taken into account is the difference in sex hormones [13].

\section{Distribution of lithiasis patients according to educational level}

Regarding educational level (tab. 1), the results showed that a large proportion of lithiasis patients have a university education level (40\%), followed by patients with a secondary level (26\%), and illiterates (14\%). Finally, the least affected by lithiasis are those with a primary level (11\%).

\section{Patient history}

\section{The medical consultation}

The consultation with a qualified doctor is an integral part of the process in treatment, also aims at patient safety. Besides, the consultation can help in diagnosing disease and to determine the appropriate treatment. The patient may expose themselves to risk if they avoid consulting a doctor [22, 23]. In the present work, the results showed that $96 \%$ of those interviewed consulted a doctor to treat kidney stones, while $4 \%$ did not consult the doctor. Our result shows that the majority of patients who use medicinal plants have a higher level of awareness and education.

\section{Monitoring and effectiveness of treatment}

The most common methods used to treat kidney stones are ESWL lithotripsy and medication therapy [24]. In the present work, among $96 \%$ of the patients who consulted the doctor, $92 \%$ followed their medications treatment, while $8 \%$ of people did not follow the treatment (fig. 2a). On the other hand, among patients who followed their treatment, 53\% confirmed that the medications treatment was effective, while 47 confirmed the ineffectiveness of the medications in the treatment (fig. 2b). Studies have shown that there is no satisfactory medication to use in clinical treatment despite significant progress in studying the biological and physical aspects of kidney stones. Also, despite the great development in the

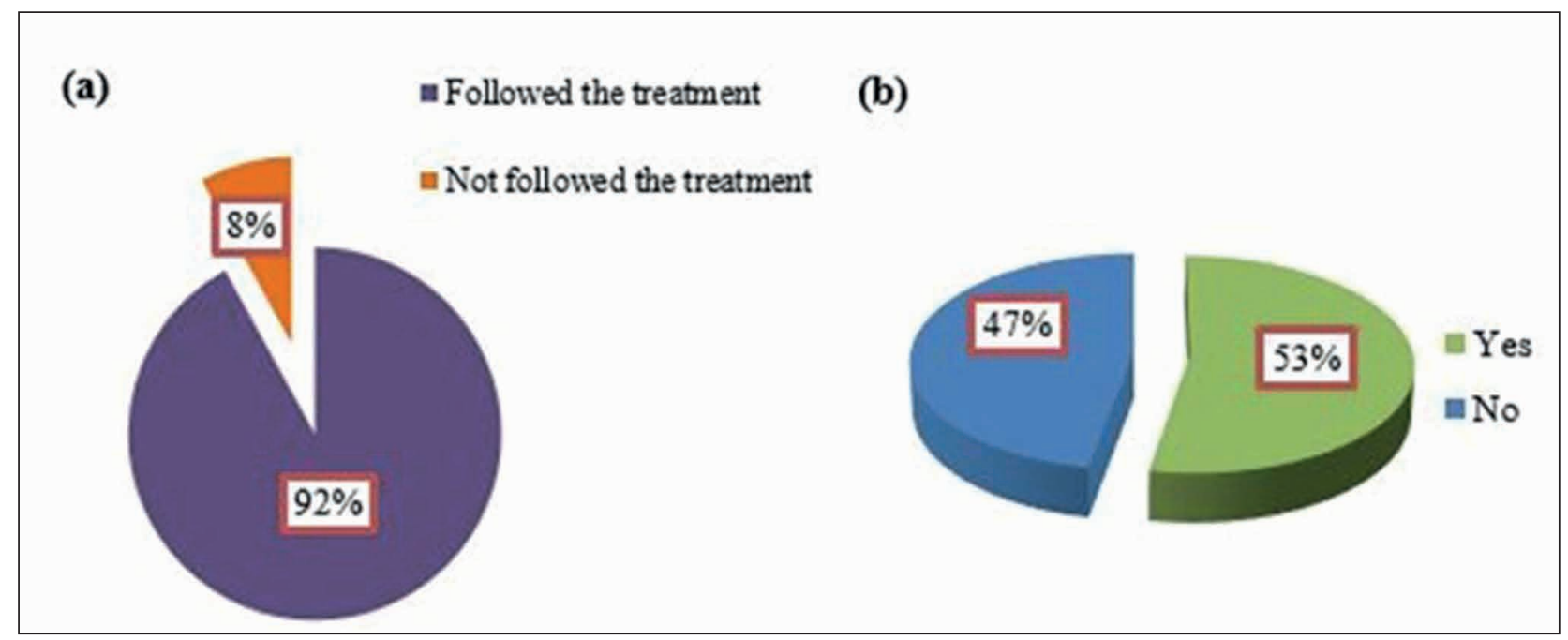

Figure 2.

Distribution of lithiasis patients by treatment follow-up (a) and by treatment effectiveness (b) 
techniques used to break up the kidney stones, data indicate that exposure to shock waves in therapeutic doses may cause acute kidney injury, a decrease in kidney function, and an increase in the frequency of the stone. Besides, residual stone fragments remaining and the possibility of infection after ESWL are a serious problem in treating stones [24-26]. On the other hand, many studies in vitro, in vivo and clinical trials have proven that phytotherapeutic agents can be useful either as an alternative therapy or as an aid in managing urolithiasis [24, 27-29].

\section{Phytotherapy}

Use of medicinal plants in the treatment of lithiasis diseases

In the present survey, 184 patients with renal calculi were questioned, of which $92 \%$ from them use medicinal plants to treat kidney stones, while patients who did not use herbal remedies had the lowest rate $(8 \%)$. In fact, many studies have reported that the percentage of the uses of medicinal plants oscillated between 55 and $95 \%$, according to the region where the survey was undertaken. The rate of use of the medicinal plants' changes according to area, ethnology, the richness of the sector in medicinal plants and home environment [31-34]. Throughout history, medicinal plants have been used in the treatment of many diseases due to their lack of side effects [35-36.] Moreover, natural products have played a significant role throughout the world in treating and preventing human illness. However, herbal medicines are regarded as an acceptable, cheap, easily available, and safe source of active constituents for pharmaceutical industry [36]. In Morocco, even today, plant medicines are freely available to the public without a prescription. As shown in figure 3, among 184 patients with lithiasis, $30.61 \%$ from them use medicinal plants before synthetic drugs, $36.73 \%$ from them use medicinal plants after synthetic drugs and 32.65\% from them use herbals in parallel with synthetic drugs. These results are attributed to several factors, including 1) erroneous belief that herbal products are superior to synthetic drugs, 2) patients' belief that their physicians have not properly identified the problem, hence the feeling that herbal remedies are another option, 3) and dissatisfaction with the results from orthodox pharmaceuticals and the belief that herbal medicines might be effective in the treatment of kidney stones.

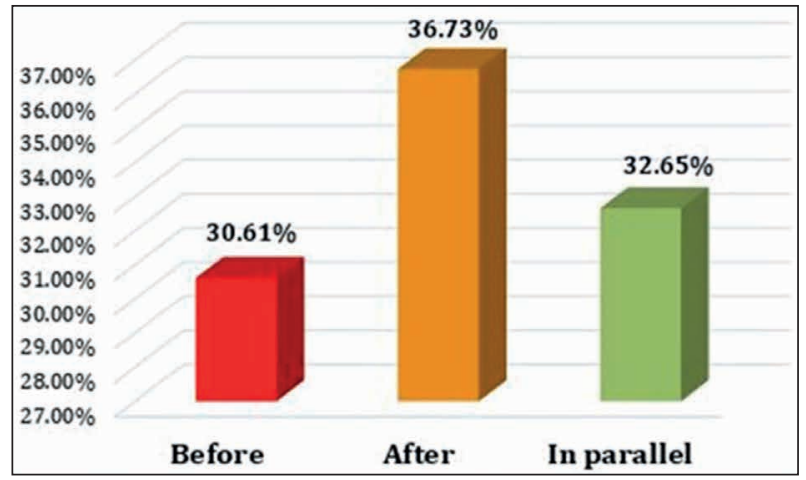

Figure 3.

Frequency of use of medicinal plants with synthetic drug treatment

Among the strategies used in preventing and treating kidney stones is the use of medicinal plants (Herbs). In the present work, the results of the survey indicated that many lithiasis patients use various species of plants for treatment, as shown in the figure 4 . The species with the highest frequency of mentions in the interview were Petroselinum crispum (Mill.) Fuss., (28\%), Herniaria hirsuta L. (25\%), Zea mays L. (12\%), Urtica dioica L. (6\%), and others (29\%).

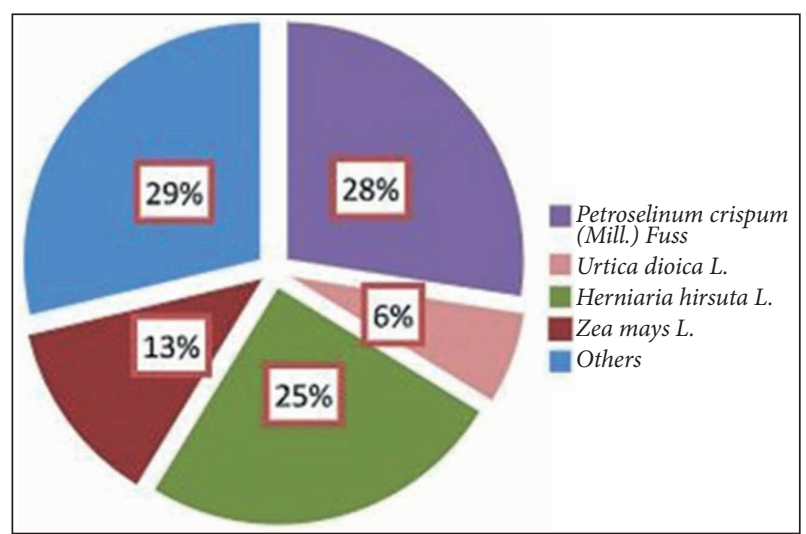

Figure 4.

Frequency of use of medicinal plants by lithiasis patients

- Petroselinum crispum (Mill.) Fuss. Parsley is an herb belonging to the Apiaceae family. This plant is distributed mainly in the Mediterranean regions, western Asia and several European countries $[37,38]$. As a complementary/alternative treatment, parsley and its extracts were used to treat various renal diseases [39-41]. The anti-urolithiasis of $P$. crispum was demonstrated in rat, as the results showed the ability of parsley extracts to prevent precipitation of calcium oxalate, urine 
supersaturation, and urinary protein excretion. Moreover, parsley extract regulates $\mathrm{pH}$ of urine at a value at which calcium oxalate crystals could be maintained as dispersed particles, and the elimination of these crystals could be facilitated [42].

- Herniaria hirsuta L. is a flowering plant belonging to the family of Caryophyllaceae. In traditional folk medicine, lithotriptic and anti-lithogenic properties have been attributed to Herniaria species [43]. $H$. hirsuta is a Mediterranean traditional medicinal plant widely used in Morocco to treat lithiasis patients [44, 45]. Its aqueous extract exerted a significant preventive effect against the formation of calcium oxalate kidney stones [43, 45]. Also, studies have proven the effectiveness of $H$. hirsuta plant in treating kidney disease, in addition to its effective role in prevention against the formation of urinary stones via inhibiting the deposition and growth of calcium oxalate crystals $[28,46]$.

- Zea mays L. is a flowering plant (variously called maize or corn) belonging to the Poaceae family. It is a medicinal plant used in the treatment of urinary tract and kidney stones [47]. It was the herbal medicine cited most often as a diuretic and antilithiasic [48, 49].

- Urtica dioica L. (stinging nettle) is a perennial plant belonging to the family of Urticaceae [50, 51]. The activity of this plant in treating urinary tract problems and kidney stones has been proven throughout history. Various extracts of $U$. dioi$c a$, including methanolic extract, decreased urine creatinine level, and reduction of supersaturation of lithogenic enhancing agents [50].

- Other medicinal plants: Citrus limon (L.) Osbeck, Malus domestica Borkh, Zizyphus lotus L. (Desf.), Origanum compactum Benth., Ocimum basilicum L., Verbena officinalis L., Allium cepa L., Cuminum cyminum L., Syzygium aromaticum (L.) Merr. \& L. M. Perry, Cucurbita pepo L., Linum usitatissimum L., and Allium sativum L. are also used in the treatment of kidney stones.

In line with this, the utilization of abovementioned medicinal plants for self-medication by patients with urinary stones varies from one to another. In our study, it was found that $65.50 \%$ of patients used them to expel kidney stones, $25 \%$ to potentiate the action of synthetic drugs, $11.80 \%$ used them because they were influenced by their culture of used herbal remedies to treat kidney stones and $8.60 \%$ of them used herbs for their low cost (fig. 5).

On the other hand, most of our lithiasis patients select these herbal medicines based on anecdotal information from other patients who experienced a kidney stone before (55\%), followed by viva voce from person to person with a percentage of $25 \%$. Herbalists represent 14\%, and the media 6\% (fig. 6).

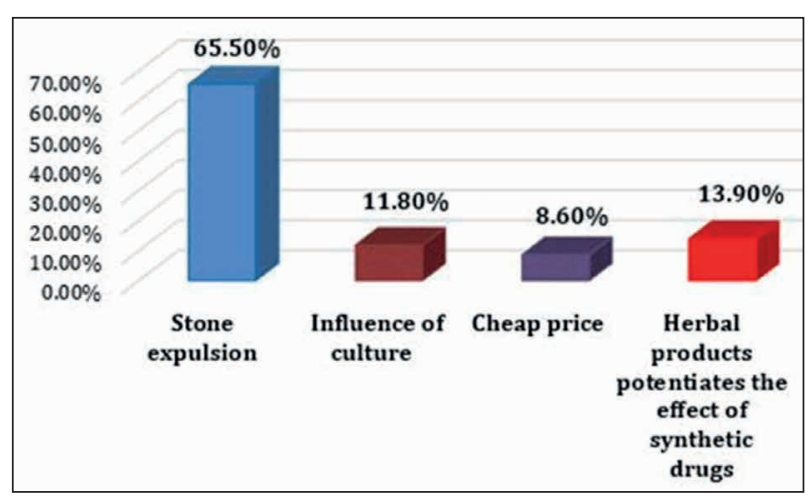

Figure 5.

The reason for the use of medicinal plants by lithiasis patients

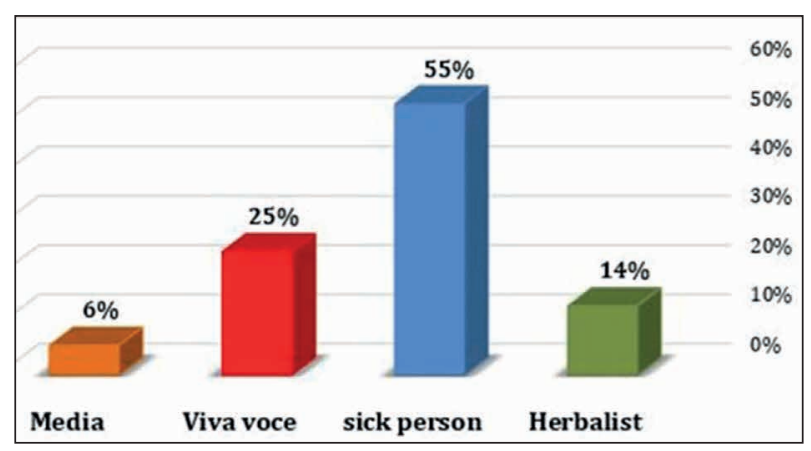

Figure 6.

The sources of information regarding the use of medicinal plants

\section{The mode of preparation}

The mode of preparation of these herbal medicines was grouped into three categories (fig. 7). The most commonly used methods of preparation were decoction (64\%) followed by infusion (26\%), and powder (10\%). The preparation of decoction for the treatment of kidney stones is a common practice among communities in Morocco [52] and other parts of the World [47]. Decoctions can often be found as one of major forms of drug preparation in ethnobotanical practice as it is easy to prepare by boiling the plant parts in water until the volume of the water reduced to a minimum or required amount [53]. On the other hand, the use of the decoction shows that the population has confidence in this type of preparation and finds it suitable for warming the body and disinfecting the plant, also the decoction makes it possible to collect the most active ingredients attenuates or cancels the toxic effect of certain recipes [54]. 


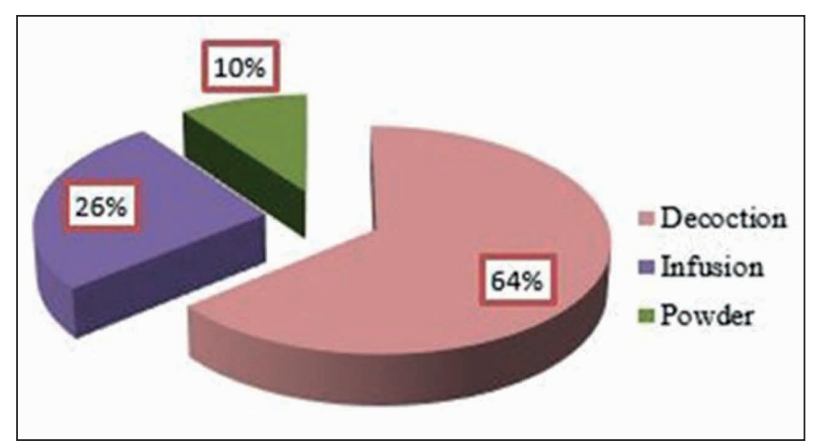

Figure 7.

Method of preparation of herbal medicines by the studied patients

\section{Dose determination}

Over a half of patients (51\%) weighed their phytodrugs with hand when preparing, then come spoon (28\%) and $21 \%$ of patients does not use a precise dose. Petroselinum crispum and Herniaria hirsuta are often used by the handful while Urtica dioica and Zea mays are used in imprecise doses by the majority of patients, as other plants pointed in table 2 . These reports are in coherence with previous study revealing the predominance of a handful of weight used in the preparation of different herbal remedies $[55,56]$. Most users of herbal medicines do not respect the doses and do not consider that high doses can be toxic and even fatal. Nearly 500 years ago, Swiss physician and chemist Paracelsus expressed the basic principle of toxicology: "All things are poison and nothing is without poison; only the dose makes a thing, not a poison". This is often condensed to: "The dose makes the poison." It means that a substance that contains toxic properties can cause harm only if it occurs in a high enough concentration [57].

\section{Frequency and duration of use}

According to each patient, medicinal plants are applied one to several times a day to treat kidney stones. In this study, only $7 \%$ of the remedies were taken one time a day, $52 \%$ two times a day, $19 \%$ three times a day, and $25 \%$ several times a day (fig. $8 \mathrm{a})$. The duration of the treatment with the plants varied considerably, according to the patients questioned ranging from few days to several years. Indeed, $6 \%$ of lithiasis patients used the plants from

Table 2.

The doses used for each plant

\begin{tabular}{lccccc}
\hline Plant dose & $\begin{array}{c}\text { Petroselinum } \\
\text { crispum [\%] }\end{array}$ & $\begin{array}{c}\text { Urtica dioica } \\
{[\%]}\end{array}$ & $\begin{array}{c}\text { Herniaria hirsuta } \\
{[\%]}\end{array}$ & $\begin{array}{c}\text { Zea mays } \\
{[\%]}\end{array}$ & $\begin{array}{c}\text { Others } \\
{[\%]}\end{array}$ \\
\hline Pinch & 0 & 20 & 5 & 10 & 0 \\
\hline Spoon & 18.18 & 20 & 30 & 40 & 13.04 \\
\hline Handle & 45.45 & 20.00 & 35.00 & 0 & 39.13 \\
\hline Not precise & 36.36 & 40.00 & 30.00 & 50.00 & 47.82 \\
\hline
\end{tabular}

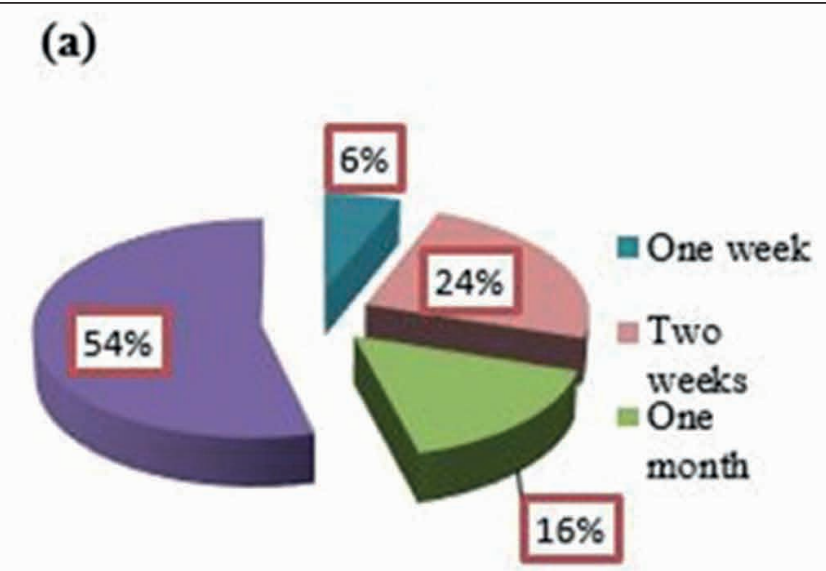

(b)

Figure 8.

Frequency (a) and duration (b) of the use of medicinal plants in the treatment of kidney stones 
one week only, $24 \%$ from 2 weeks, $16 \%$ from one month, and $54 \%$ until healing (fig. 8b). The duration of the treatment sometimes may be extended for a long period depending on the severity of the disease, age of the patient, and the diet they used to take from childhood onwards [58].

\section{Plants toxicity}

Although medicinal plants are often promoted as natural and therefore harmless, they are not free from adverse effects. In this study, more than $67 \%$ of people with lithiasis had no information on the toxicity of medicinal plants and only $33 \%$ took it into account. The patients who knew the toxicity of herbs revealed that the adverse effects of plants are related to the mode of preparation of plant (13\%), used parts $(11 \%)$, as well as plant type or the plant phytochemistry (9\%). In general, the toxicity varies from one plant to another depending on compounds present in each plant in addition to their concentrations. Other parameters may also cause toxicity in some plants, including the dose consumed, the strength of secondary metabolites, genetic differences within the species and the consumed part of the plant (root, oil, leaves, stem bark, and seeds). Moreover, there are parameters related to the human's body and physiological condition, as well as the time of the dose administration and time of exposure $[59,60]$.

\section{CONCLUSION}

Medicinal plants have an important place in the treatment of kidney lithiasis in patients in eastern region, both men and women. Indeed, $92 \%$ of patients resort to medicinal plants, mainly Petroselinum crispum, Herniaria hirsuta, Zea mays, and Urtica dioica, to relieve their pain and expel lithiasis, without taking into account that these pla nts have adverse effects which may appear either through the incorrect identification of the plant or their parts or through their inappropriate uses. Thus, the intellectual level of the patient is not a criterion that measures the consciousness of the population, since only $8 \%$ of the people interviewed were aware of the harmful complications that can occur. For this, medicinal plants must, like medicines, comply with strict requirements and standard rules of use to which only the specialist in herbal medicine can respond and sensitize people to the dangers of irrational consumption of medicinal plants.
Conflict of interest: Authors declare no conflict of interest.

\section{REFERENCES}

1. Daudon M, Traxer O, Lechevallier E, Saussine C. Épidémiologie des lithiases urinaires. Progrès en Urol 2008; 18:802-14. doi: https://dx.doi. org/10.1016/j.purol.2008.09.029

2. Badalato GM, Cortes JAS, Gupta M. Treatment of upper urinary lithiasis in patients who have undergone urinary diversion. Curr Urol Rep 2011; 12(2):121-125. doi: https://dx.doi.org/10.1007/ s11934-011-0175-3

3. Wasserstein AG. Epidemiology and natural history of nephrolithiasis. Clin Rev Bone Miner Metab 2011; 9(3-4):165-180. doi: https://dx.doi. org/10.1007/s12018-011-9097-3

4. Knoll T. Stone Disease. Eur Urol Suppl. 2007; 6:717-722.

5. Davoudi-Kiakalayeh A, Mohammadi R, Pourfathollah AA, Siery Z, Davoudi-Kiakalayeh S. Alloimmunization in thalassemia patients: new insight for healthcare. Int J Prev Med 2017; 8. doi: https://dx.doi.org/10.4103/ijpvm.IJPVM_246_16

6. Ramello A, Vitale C, Marangella M. Epidemiology of nephrolithiasis. J Nephrol 2000; 13:S45-50.

7. Tabuti JRS, Lye KA, Dhillion SS. Traditional herbal drugs of Bulamogi, Uganda: plants use and administration. J Ethnopharmacol 2003; 88:19-44. doi: https://dx.doi.org/10.1016/S03788741(03)00161-2

8. Encyclopédie des plantes médicinales. Larousse, 2001. pdf, https://assomaleva.files.wordpress.com/ 2016/02/larousse-des-plantes-medicinales.pdf

9. Bellakhdar J, Plantes médicinales au Maghreb et soins de bases. Précis de phytothérapie moderne. Casablanca. Éditions Le Fennec, 2019.

10. George P. Concerns regarding the safety and toxicity of medicinal plants - An overview. J Appl Pharm Sci 2011; 01(06):40-44.

11. Jamila F, Mostafa E. Ethnobotanical survey of medicinal plants used by people in Oriental Morocco to manage various ailments. J Ethnophar- 
macol 2014; 154(1):76-87. doi: https://dx.doi. org/10.1016/j.jep.2014.03.016.

12. http://www.theplantlist.org.

13. Guerrouj B El, Bouhrim M, Bentata Y, Daudon M, Melhaoui M, Kharchoufa L et al. Kidney stone disease (Urolithiasis): epidemiological study in the Eastern region of Morocco. Eur J Sci Res 2019; 155:40-57.

14. El Guerrouj B, Bouhrim M, Bencheikh N, Imtara $\mathrm{H}$, Kharchoufa L, Ouassou $\mathrm{H}$ et al. Morphological and crystallographic analysis of kidney stones in Eastern. Mediterr J Chem 2020; 10(5):539-546. doi: http://dx.doi.org/10.13171/ mjc10502005261409hi

15. Bartoletti R, Cai T, Mondaini N, Melone F, Travaglini F, Carini M, Rizz M. Epidemiology and risk factors in urolithiasis. Urol Int 2007; 79(suppl. 1):3-7. 10.1159/000104434

16. Laziri F, Rhazifilali F, Amchhoud I. Etude rétrospective de la lithiase urinaire dans l'Hôpital Hassan II de la province de Settat (Maroc). African J Urol 2009; 15(2):117-123. [in French]

17. Boumzaoued H, Laziri F, Lekhlifi Z El, Qarro A, Assyry A El. Prevalence of urinary lithiasis in the Moulay Ismail Military Hospital (Meknes-Morocco). J Mat Environ Sci 2015; 6(6):1578-1583.

18. Bouatia M, Benramdane L, Idrissi MOB, Draoui M. An epidemiological study on the composition of urinary stones in Morocco in relation to age and sex. African J Urol 2015; 21(3):194-197. doi: https://dx.doi.org/10.1016/j.afju.2015.02.006

19. Muslumanoglu AY, Binbay M, Yuruk E, Akman T, Tepeler A, Esen T, Tefekli AH. Updated epidemiologic study of urolithiasis in Turkey. I : Changing characteristics of urolithiasis. Urol Res 2011; 39(4):309-314. doi: https://dx.doi.org/10.1007/ s00240-010-0346-6

20. Ramirez CT, Morales EF, Gomez AZ, Alcaraz LG, Samper SDR. An epidemiological study of renal lithiasis in gypsies and others in Spain. J Urol 1984; 131(5):853-856. doi: https://dx.doi. org/10.1016/S0022-5347(17)50679-5

21. Johnson CM, Wilson DM, Fallon WMO, Malek RS, Kurland LT. Renal stone epidemiology: A 25-year study in Rochester, Minnesota. Kid- ney Int 1979; 16(5):624-631. doi: https://dx.doi. org/10.1038/ki.1979.173

22. Longtin Y, Sax H, Leape LL, Sheridan SE, Donaldson L, Pittet D. Patient Participation: Current knowledge and applicability to patient safety. Mayo Clin Proc 2010;85(1):53-62. doi: https:// dx.doi.org/10.4065/mcp.2009.0248

23. World Health Organization. Topic 6: Understanding and managing clinical risk. Patient Saf Curr Guid 2015; 151-164.

24. Butterweck V, Khan SR. Herbal medicines in the management of urolithiasis : Alternative or complementary? Planta Med 2009; 75(10):1095-1103. doi: https://dx.doi.org/10.1055/s-0029-1185719

25. Nabi G, Downey P, Keeley F, Watson G, Mcclinton S. Extra-corporeal shock wave lithotripsy (ESWL) versus ureteroscopic management for ureteric calculi (review). Cochrane Database Syst Rev 2007; (4). doi: https://dx.doi. org/10.1002/14651858.CD006029

26. Dellabella M, Milanese G, Muzzonigro G. Medical-expulsive therapy for distal ureterolithiasis: randomized prospective study on role of corticosteroids used in combination with tamsulosin-simplified treatment regimen and health-related quality of life. Urology 2005; 66(4):0-3. doi: https://dx.doi.org/10.1016/j.urology.2005.04.055

27. Barros ME, Schor N, Boim MA. Effects of an aqueous extract from Phyllanthus niruri on calcium oxalate crystallization in vitro. Urol Res 2003; 30:374-379. doi: https://dx.doi.org/10.1007/ s00240-002-0285-y

28. Atmani F, Farell G, Lieske JC. Extract from Herniaria hirsuta coats calcium oxalate monohydrate crystals and blocks their adhesion to renal epithelial cells. J Urol 2004; 172(4 Part 1):1510-1514. doi: https://dx.doi.org/10.1097/01. ju.0000131004.03795.c5

29. Oussama A, Touhami M, Mbarki M. In vitro and in vivo study of effect of lemon juice on urinary lithogenesis. Arch Esp Urol 2005; 58(10):1.0871.092. doi: https://dx.doi.org/10.4321/S000406142005001000019

30. Ruth H, Laube N, Schneider A, Kessler T, Hesse A. Influence of grapefruit-, orange- and apple- 
juice consumption on urinary variables and risk of crystallization. Br J Nutr 2003; 90:295-300. doi: https://dx.doi.org/10.1079/BJN2003897

31. Jouad H, Haloui M, Rhiouani H, Hilaly J El, Eddouks M. Ethnobotanical survey of medicinal plants used for the treatment of diabetes, cardiac and renal diseases in the North centre region of Morocco (Fez - Boulemane). J Ethnopharmacol 2001; 77:175-182. doi: https://dx.doi.org/10.1016/ S0378-8741(01)00289-6

32. Ziyyat A, Legssyer A, Mekhfi H, Dassouli A, Serhrouchni M, Benjelloun W. Phytotherapy of hypertension and diabetes in oriental Morocco. J Ethnopharmacol 1997; 58(1):45-54. doi: https:// dx.doi.org/10.1016/S0378-8741(97)00077-9

33. Eddouks M, Maghrani M, Lemhadri A, Ouahidi $M$, Jouad $H$. Ethnopharmacological survey of medicinal plants used for the treatment of diabetes mellitus, hypertension and cardiac diseases in the south-east region of Morocco (Tafilalet). J Ethnopharmacol 2002; 82:97-103. doi: https:// dx.doi.org/10.1016/S0378-8741(02)00164-2

34. Bellakhdar J, Claisse R, Fleurentin J, Younos C. Repertory of standard herbal drugs in the Moroccan pharmacopoea. J Ethnopharmacol 1991; 35:123-143. doi: https://dx.doi.org/10.1016/03788741(91)90064-K

35. Nasri H, Shirzad H. Toxicity and safety of medicinal plants. J Herb Med Pharmacol 2013; 2:21-22.

36. Asadbeigi M, Mohammadi T, Rafieian-Kopaei M, Saki K, Bahmani M, Delfan M. Traditional effects of medicinal plants in the treatment of respiratory diseases and disorders: an ethnobotanical study in the Urmia. Asian Pac J Trop Med 2014; 7(Suppl. 1):364-368. doi: https://dx.doi. org/10.1016/S1995-7645(14)60259-5

37. Farzaei MH, Abbasabadi Z, Ardekani MRS, Rahimi R, Farzaei F. Parsley: a review of ethnopharmacology, phytochemistry and biological activities. J Tradit Chinese Med 2013; 33(6):815826. doi: https://dx.doi.org/10.1016/s02546272(14)60018-2

38. Zhang $\mathrm{H}$, Chen F, Wang X, Yao H. Evaluation of antioxidant activity of parsley (Petroselinum crispum) essential oil and identification of its antioxidant constituents. Food Res Int 2006;
39:833-839. doi: https://dx.doi.org/10.1016/j. foodres.2006.03.007

39. Rezazad M, Farokhi F. Protective effect of Petroselinum crispum extract in abortion using prostadin-induced renal dysfunction in female rats. Avicenna J Phytomed 2014; 4(5):312-319.

40. Kreydiyyeh SI, Usta J. Diuretic effect and mechanism of action of parsley. J Ethnopharmacol 2002; 79:353-357. doi: https://dx.doi.org/10.1016/ S0378-8741(01)00408-1

41. Vamenta-Morris H, Dreisbach A, ShoemakerMoyle M, Abdel-Rahman EM. Internet claims on dietary and herbal supplements in advanced nephropathy: Truth Myth Am J Nephrol 2014; 40(5):393-388. doi: https://dx.doi. org/10.1159/000368724

42. Al-yousofy F, Gumaih H, Ibrahim H, Alasbahy A. Parsley! Mechanism as antiurolithiasis remedy. J Clin Exp Urol 2017; 5(3):55-62.

43. Atmani F, Khan S. Effects of an extract from Herniaria hirsuta on calcium oxalate crystallization in vitro. Bju Int 2000; 85(6):621-625. doi: https:// dx.doi.org/10.1046/j.1464-410x.2000.00485.x

44. Atmani F, Slimani Y, Mimouni M, Hacht B. Prophylaxis of calcium oxalate stones by Herniaria hirsuta on experimentally induced nephrolithiasis in rats. Bju Int 2003; 92(1):137-140. doi: https:// dx.doi.org/10.1046/j.1464-410X.2003.04289.x

45. Atmani F, Slimani Y, Mimouni M, Aziz M, Hacht B, Ziyyat A. Effect of aqueous extract from Herniaria hirsuta L. on experimentally nephrolithiasic rats. J Ethnopharmacol. 2004;95:87-93. doi: https://dx.doi.org/10.1016/j.jep.2004.06.028

46. Fouad A, Yamina S, Nait MA, Mohammed B, Abdlekrim R. In vitro and in vivo antilithiasic effect of saponin rich fraction isolated from Herniaria hirsuta. J Bras Nefrol 2006; 28(4):199-203.

47. Prachi, Chauhan N, Kumar D, Kasana M. Medicinal plants of Muzaffarnagar district used in treatment of urinary tract and kidney stones. Indian J Trad Knowledge 2009; 8(2):191-195.

48. Grases F, March J, Ramis M, Costa-Bauza A. Influence of Zea mays on urinary risk factors for kidney stones in rats. Phytother Res 1993; 7:146-149. doi: https://dx.doi.org/10.1002/ptr.2650070210 
49. Velazquez DVO, Xavier HS, Batista JEM, Castro-chaves C De. Zea mays L. extracts modify glomerular function and potassium urinary excretion in conscious rats. Phytomedicine 2005; 12:363-369. doi: https://dx.doi.org/10.1016/j. phymed.2003.12.010

50. Zhang H, Li N, Li K, Li P. Protective effect of Urtica dioica methanol extract against experimentally induced urinary calculi in rats. Mol Med Rep 2014; 10:3157-3162. doi: https://dx.doi. org/10.3892/mmr.2014.2610

51. Durak I, Biri H, Devrim E, Sözen S, Avci A. Aqueous extract of Urtica dioica makes significant inhibition on adenosine deaminase activity in prostate tissue from patients with prostate cancer. Cancer Biol Ther 2004; 3(9):855-857. doi: https://dx.doi.org/10.4161/cbt.3.9.1038

52. Ammor K, Mahjoubi F, Bousta D, Chaqroune A. Ethnobotanical survey of medicinal plants used in the treatment of kidney stones in region of Fez-Meknes, Morocco Kenza. Ethnobot Res Appl 2020; 19:1-12.

53. Silambarasan R, Ayyanar M. An ethnobotanical study of medicinal plants in Palamalai region of Eastern Ghats, India. J Ethnopharmacol 2015; 172:162-178. doi: https://dx.doi.org/10.1016/j. jep.2015.05.046

54. Salhi S, Fadli M, Zidane L, Douira A. Etudes floristique et ethnobotanique des plantes médicinales de la ville de Kénitra (Maroc). LAZAROA 2010; 31:133-146. [in Frech] doi: https://dx.doi. org/10.5209/rev_LAZA.2010.v31.9
55. Benkhnigue O, Zidane L, Fadli M, Elyacoubi H, Rochdi A, Douira A. Etude ethnobotanique des plantes médicinales dans la région de Mechraâ Bel Ksiri (Région du Gharb du Maroc). Acta Bot Barcinonensia 2011; 53:191-216. [in French]

56. El Hassani M, Douiri E., Bammi J, Zidane L, Badoc A, Douira A. Plantes médicinales de la Moyenne Moulouya (Nord-Est du Maroc). Ethnopharmacologia 2013; 50:39.

57. Four treatises of Theophrastus von Hohenheim called Paracelsus. Sigerest H (ed.). Baltimore. Johns Hopkins University Press, 1996.

58. Savithramma N, Sulochana C, Rao KN. Ethnobotanical survey of plants used to treat asthma in Andhra Pradesh, India. J Ethnopharmacol 2007; 113:54-61. doi: https://dx.doi.org/10.1016/j. jep.2007.04.004

59. Kharchoufa L, Merrouni IA, Yamani A, Elachouri M. Profile on medicinal plants used by the people of North Eastern Morocco: Toxicity concerns. Toxicon 2018; 154:90-113. doi: https://dx.doi. org/10.1016/j.toxicon.2018.09.003

60. Tülay AC. Potential genotoxic and cytotoxic effects of plant extracts. In: Bhattacharya A (ed.). A compendium of essays on alternative therapy. IntechOpen, 2012; 211-228. 